Pobrane z czasopisma Annales I - Philosophy and Sociology http://philosophia.annales.umcs.pl Data: 26/04/2023 14:22:56

DOI: 10.17951/i.2016.41.2.61

A N N A LES

UNIVERSITATIS MARIAE CURIE-SKŁODOWSKA

LUBLIN - POLONIA

VOL. XLI, 2

SECTIO I

2016

RENATA BOGUSZ

Uniwersytet Medyczny w Lublinie

MICHAŁ NOWAKOWSK I

Uniwersytet Marii Curie-Skłodowskiej w Lublinie

Poglądy studentów pielęgniarstwa na temat stanów, zachowań i naturalnych procesów biologicznych poddawanych medykalizacji

Nursing Students' Opinions on the Conditions, Behaviors and Natural Biological Processes Which Are Being Medicalized

\title{
WPROWADZENIE
}

Koncepcja medykalizacji pojawiła się jako krytyka profesji medycznej, a zwłaszcza medycznej władzy. Stanowiła ona reakcję wobec dominacji wiedzy eksperckiej i biomedycznego modelu zdrowia. Krytyka procesów medykalizacji może być totalna (np. w wykonaniu Ivana Illicha ${ }^{1}$ ) lub częściowa, tzn. może polegać na uznaniu, że większość przejawów medykalizacji jest naukowo uzasadniona i należy skupić się jedynie na tych, które takiego uzasadnienia nie mają.

Rosnąca rola medycyny często była przedstawiana jako rozprzestrzenienie się nowej formy społecznej kontroli - szczególnie kontroli nad kobiecym ciałem czy nad zachowaniami sprzecznymi z obowiązującymi normami. Przykładowo Irving Zola określił medykalizację jako „proces, w którym coraz większa część życia codziennego podlega władzy, wpływowi i nadzorowi medycyny" ${ }^{2}$. Dla wielu

1 I. Illich, Medical Nemesis. The Expropriation of Health, New York 1976.

2 I. Zola, Socio-medical Inquiries: Recollections, Reflections, and Reconsiderations, 
Pobrane z czasopisma Annales I - Philosophy and Sociology http://philosophia.annales.umcs.pl Data: 26/04/2023 14:22:56

znaczących krytyków medykalizacji (nawet tych, którzy tego pojęcia nie stosowali) była ona związana $\mathrm{z}$ intencjonalnym kierowaniem się interesem medycyny przez zapewnianie hegemonii w definiowaniu i zarządzaniu zdrowiem i chorobą ${ }^{3}$. Medykalizację, medyczny imperializm, rozumiano jako „ekspansjonistyczne ambicje drapieżnej profesji” ${ }^{4}$. Krytyka tego typu była często wzbogacana o opisy współpracy medycyny z mniej lub bardziej jawnie opresyjnym państwem.

Jednak coraz mocniej widoczne i dojmujące przemiany w ramach współczesnego kapitalizmu (rozmontowanie stałych struktur, podziałów, hierarchii i powstanie silnych, ulokowanych na poziomie ponadnarodowym ośrodków władzy w postaci transnarodowych korporacji, posługujących się całkiem nowym modelem biznesowym, powstanie ponowoczesnego konsumeryzmu i konsumentów o określonych postawach) oraz dostrzeżenie faktu, iż zakres i siła władzy lekarzy były co najmniej przeszacowane, spowodowały, że ostrze krytyki zostało skierowane nie tylko w nich, ale także w kierunku innych domniemanych beneficjentów medykalizacji: przemysłu farmaceutycznego, klasy kapitalistów, państwa oraz organizacji pacjenckich ${ }^{5}$. Fakt, że w procesie medykalizacji zaczęli odgrywać istotną rolę nowi aktorzy, doprowadził do tego, że sam proces stał się czymś innym. Ową zmianę dobrze ilustrują dwie definicje autorstwa Petera Conrada. W artykule z 1975 r. medykalizacją dla niego było „definiowanie zachowania jako problemu medycznego lub choroby i uprawnianie medycyny do ich leczenia" ${ }^{\text {, }}$ natomiast w 1992 r. określił ją jako socjo-kulturowy proces, w którym mogą, ale nie muszą uczestniczyć przedstawiciele zawodów medycznych. Medykalizacja to, według niego, definiowanie problemu w medycznych terminach, korzystanie

Philadelphia 1983, za: J.E. Davis, How medicalization lost its way, "Society" 2006, Vol. 43 (6), DOI: http://10.1007/bf02698486, s. 53.

3 T. Szasz, The myth of mental illness, "American Psychologist" 1960, No. 15, DOI: http:// dx.doi.org/10.1037/h0046535, s. 113-118. 1960; E. Goffman, Asylums: Essays on the Social Situation of Mental Patients and Other Inmates, Doubleday (New York City) 1961; E. Freidson, Profession of Medicine: A Study of the Sociology of Applied Knowledge, New York 1970; I.K. Zola, Medicine as an institution of social control, "Sociological Review" 1970, Vol. 20, DOI: http://10.1111/j.1467-954X.1972.tb00220.x, s. 487-504; M. Foucault, Nadzorować i karać. Narodziny więzienia, Warszawa 1998; I. Illich, op. cit.; P. Conrad, The discovery of hyperkinesis: Notes on the medicalization of deviant behavior, "Social Problems" 1975, Vol. 23 (1), DOI: http://dx.doi.org/10.2307/799624, s. 12-21; idem, Types of medical social control, "Sociology of Health and Illness" 1979, Vol. 1 (1), DOI: http://10.1111/j.1467-9566.1979.tb00175.x, s. 1-11.

4 F. Furedi, The end of professional dominance, "Society" 2006, Vol. 43 (6), DOI: http://10.1007/BF02698479, s. 14-18.

5 Ibidem.

6 P. Conrad, The discovery of hyperkinesis..., s. 12-21; idem, Medicalization and social control, "Annual Review of Sociology" 1992, Vol. 18, DOI: http://10.1146/annurev.so.18.080192.001233, s. 210 . 
Pobrane z czasopisma Annales I - Philosophy and Sociology http://philosophia.annales.umcs.pl Data: 26/04/2023 14:22:56

Poglądy studentów pielęgniarstwa na temat stanów, zachowań...

63

z języka medycyny do jego opisu i medycznych interwencji, by go rozwiązać ${ }^{7}$. Jak zauważył Davis, w gruncie rzeczy Conrad i inni odłączyli medykalizację od instytucji medycyny w celu nadania temu terminowi większej „,pojemności” oraz możliwości uogólniania ${ }^{8}$.

W takich warunkach procesy medykalizacji stają się wszechogarniającym zjawiskiem, które jest inicjowane i kształtowane przez rozmaitych aktorów - oprócz lekarzy są to również firmy farmaceutyczne i ubezpieczeniowe, instytucje publiczne, organizacje pacjenckie i instytucje non-profit, przedstawiciele tzw. medycyny alternatywnej i komplementarnej, laicy/opinia publiczna. Ich działania wynikają z rozmaitych pobudek: ekonomicznych, politycznych, nawet osobistych, ale wszystkie są przejawem dominacji medycznego czy, szerzej, terapeutycznego sposobu myślenia.

W ten sposób medykalizacja, jako proces rozproszony i niewidoczny, zachodzi na różnych poziomach. Jest to przenikanie medycznej interpretacji do szerszych podsystemów społecznych (prawa, pomocy społecznej, promocji zdrowia, systemów bezpieczeństwa, systemów penitencjarnych, religii, przestrzeni medialnej, systemów edukacji, gospodarki, stosunków pracy). Niemniej medykalizacja to również (a obecnie może nawet przede wszystkim) proces, który zachodzi na poziomie psychologicznym. Może zatem być społecznym fenomenem obejmującym całe populacje ludzi, różne kategorie społeczne czy tożsamości, ale także może wpływać na system znaczeń i praktyki konkretnych jednostek ${ }^{9}$. Innymi słowy to swoista gotowość zwykłych ludzi do przyjmowania medycznego/terapeutycznego sposobu definiowania własnych i cudzych problemów oraz ich rozwiązań. Bez tej gotowości wiele krytykowanych przejawów medykalizacji (najczęściej animowanych przez firmy farmaceutyczne) nie miałoby szans powodzenia.

Zasadniczym zarzutem wobec procesów medykalizacji jest nieuzasadniony redukcjonizm. Peter Conrad stwierdza, że medykalizacja staje się problemem wtedy, kiedy skomplikowane społeczno-psychologiczne zjawiska zostają sprowadzone do problemu biologicznego, który w dalszej kolejności podlega kontroli „establishmentu" medycznego, przez co jego pozostałe wymiary nie są badane ${ }^{10}$. Jeśli jako procesy medykalizacji uznamy również procesy terapeutyzacji/psychologizacji, to - parafrazując słowa Conrada - można by stwierdzić, że medykalizacja staje

7 Idem, Medicalization and social..., s. 211

8 J.E. Davis, op. cit., s. 53.

9 J.Z. Sadler, F. Jotterand, S.C. Lee, S. Inrig, Can medicalization be good? Situating medicalization within bioethics, "Theoretical Medicine and Bioethics" 2009, Vol. 30 (6), DOI: http://10.1007/ s11017-009-9122-4, s. 413.

10 P. Conrad, The Medicalization of Society: On the Transformation of Human Conditions into Treatable Disorders, Baltimore 2007, s. 146-147. 
Pobrane z czasopisma Annales I - Philosophy and Sociology http://philosophia.annales.umcs.pl Data: 26/04/2023 14:22:56

się problemem także wtedy, gdy skomplikowane zjawiska bio-psycho-społeczne zostają sprowadzone do problemu biologicznego bądź psychologicznego, a z widoku znikają nam jego uwarunkowania społeczne.

Stawiając sprawę w ten sposób, można zadać pytanie, czy we współczesnym społeczeństwie istnieje jeszcze alternatywa dla perspektywy biomedycznej i psychologicznej. Czy dominacja indywidualistycznego sposobu definiowania ludzkich problemów i metod ich rozwiązywania jest całkowita? Na pierwszy rzut oka może się wydawać, że nie. Istnieje wciąż socjologia (oraz pozostałe nauki społeczne), w tym sprzymierzone z nią zdrowie publiczne, reprezentujące perspektywę typowo społeczną. Myśleniem tego rodzaju przecież posługuje się też polityka społeczna/ zdrowotna, a zatem państwo. Ale z drugiej strony stoi ktoś potężniejszy i bardziej zdeterminowany: rynek, czyli kapitał i sformatowani na jego potrzeby konsumenci wspierani przez neoliberalną ideologię. To, co dla państwa stanowi koszt, dla kapitału jest okazją do zarobku. Nie dziwi wobec tego skłonność, z jaką instytucje publiczne pozbywają się odpowiedzialności za problemy społeczne (których częścią są problemy zdrowotne). Uznając depresję za chorobę mózgu, likwidujemy związek tzw. epidemii depresji z pogarszającymi się społecznymi warunkami życia w zamożnych społeczeństwach Zachodu: atomizacji społecznej, rosnącego rozwarstwienia ekonomicznego, niepewności na rynku pracy oraz związanej z nią rosnącej konkurencji i wymagań wobec pracowników.

Te rozważania skłoniły nas do podjęcia pilotażowych badań, które miały na celu m.in. zdiagnozowanie, w jaki sposób studenci pielęgniarstwa postrzegają różne ludzkie problemy i zachowania, które współcześnie są opisywane w literaturze jako zjawiska poddawane medykalizacji. Biorąc pod uwagę ideologiczne podstawy pielęgniarstwa, wydaje się, że studenci powinni skłaniać się ku myśleniu o człowieku i jego problemach zarówno w kategoriach medycznych, psychologicznych, jak i społecznych. Są to osoby poddawane szkoleniu medycznemu, ale zgodnie z holistycznym paradygmatem opieki pielęgniarskiej, ujmującym człowieka jako nieredukowalną bio-psycho-społeczną całość, powinny również być świadome owej złożoności ludzkich problemów i zachowań (zdecydowanie bardziej niż lekarze).

\section{CELE BADAŃ}

1. Poznanie preferowanych przez studentów pielęgniarstwa sposobów definiowania wybranych stanów, zachowań i naturalnych procesów życiowych współcześnie poddawanych medykalizacji.

2.Poznanie preferowanych przez studentów pielęgniarstwa sposobów postępowania z wybranymi stanami, zachowaniami i naturalnymi procesami życiowymi współcześnie poddawanymi medykalizacji. 
Pobrane z czasopisma Annales I - Philosophy and Sociology http://philosophia.annales.umcs.pl Data: 26/04/2023 14:22:56

Poglądy studentów pielęgniarstwa na temat stanów, zachowań...

65

3. Próba odpowiedzi na pytanie, czy socjalizacja wprowadzona do zawodu pielęgniarskiego nasila medyczny sposób postrzegania wybranych stanów, zachowań i naturalnych procesów życiowych współcześnie poddawanych medykalizacji.

4. Pierwszy etap prac nad poszukiwaniem sposobu mierzenia stopnia/poziomu zmedykalizowania jednostek i grup społecznych.

\section{MATERIAŁ I METODY}

Badania przeprowadzono w 2016 r. wśród studentów pielęgniarstwa UM w Lublinie, którzy rozpoczynali naukę na poziomie licencjackim $(62,9 \%)$ oraz kończyli na poziomie magisterskim (37,1\%). Wśród badanych mężczyźni stanowili 8,6\%, a kobiety $-91,4 \%$. Niemal co drugi respondent pochodził z małej miejscowości do 2 tys. mieszkańców (45,7\%), pozostali jako miejsce stałego zamieszkania wskazywali miejscowości o liczbie mieszkańców: od 2 do 50 tys. (35,3\%), od 50 do 100 tys. (7,8\%), od 100 tys. i więcej (11,2\%). Na uwagę zasługuje fakt, że częściej niż co trzecia osoba miała wśród bliskich kogoś z medycznym wykształceniem (38,3\%). Ponadto badani wywodzili się z rodzin, w których ojcowie mieli najczęściej wykształcenie zawodowe (wyższe - 11,2\%, średnie - 34,5\%, zawodowe - $50 \%$, podstawowe $-4,3 \%$ ), a matki - średnie (wyższe $-25 \%$, średnie $-42,2 \%$, zawodowe $-30,2 \%$ podstawowe $-2,6 \%$ ).

Udział respondentów był dobrowolny i anonimowy. W badaniu zastosowano metodę sondażu diagnostycznego oraz technikę ankiety audytoryjnej. Dane empiryczne zebrano za pomocą autorskiego kwestionariusza. Uzyskane dane poddano analizie statystycznej z zastosowaniem testu $\mathrm{Chi}^{2}$. Przyjęto poziom istotności $\mathrm{p}<0,05$ wskazujący na istnienie różnic istotnych statystycznie. Projekt sfinansowano ze środków własnych.

\section{WYNIKI}

Przystępując do realizacji badań, opracowaliśmy pytania odnoszące się do 16 stanów, zachowań i naturalnych procesów życiowych, które w ostatnich latach były poddawane procesom medykalizacji. Na potrzeby tego artykułu wybraliśmy sześć z nich, które miały formę pytań zamkniętych. Dla każdego wybranego przykładu na podstawie literatury opracowaliśmy trzy rodzaje definicji, w uproszczeniu nazwane: „biomedyczną”, „psychoterapeutyczną” oraz „społeczną” lub „niemedyczną" (niektóre definicje zostały skonstruowane w taki sposób, by studenci mogli wybrać ujęcie problemu jako „naturalny proces”, „,czynnik ryzyka” albo „chorobę”). Następnie dla każdego stanu, zachowania czy naturalnego procesu życiowego opracowaliśmy analogicznie trzy sposoby radzenia sobie z nim. Studenci 
Pobrane z czasopisma Annales I - Philosophy and Sociology http://philosophia.annales.umcs.pl Data: 26/04/2023 14:22:56

mieli wybrać jedną jako propozycję dla hipotetycznej osoby, która była dotknięta danym problemem.

\section{DEPRESJA}

Przewiduje się, że depresja będzie w przyszłości główną chorobą cywilizacyjną w społeczeństwach rozwiniętych. Według badań epidemiologicznych liczba zachorowań jest coraz większa. Jednocześnie wiadomo, że w bardzo dużym stopniu proces ten wynika ze zmian kryteriów diagnostycznych depresji (granica między zdrowiem a zaburzeniem jest coraz łatwiejsza do przekroczenia) ${ }^{11}$. Krytycy tych zmian twierdzą, że mamy do czynienia $\mathrm{z}$ nieuzasadnioną $\mathrm{w}$ dużej mierze medykalizacją złego nastroju, a także problemów o charakterze egzystencjalnym. Jednocześnie następuje równie mocno krytykowana biologizacja depresji, czyli przekształcanie jej z choroby umysłu w zaburzenie funkcjonowania mózgu ${ }^{12}$. Depresja jest więc obecnie najważniejszym przejawem medykalizacji i dlatego została wybrana jako jeden z badanych przykładów.

W postrzeganiu depresji dominował wśród badanych „niemedyczny” sposób jej definiowania: „,inaczej melancholia, poczucie braku sensu życia, ochoty do życia” (45,7\%), rzadziej wskazywano na definicję „,psychoterapeutyczną” - „okres bardzo niskiego nastroju wynikający z negatywnych przeżyć, stresów” $(33,6 \%)$, najrzadziej wybierano typowo biomedyczne określenie - ,choroba neurologiczna wynikająca ze zbyt niskiego poziomu serotoniny w mózgu" (17,2\%).

Gdyby respondenci byli poproszeni o poradę dla osoby z depresją, najczęściej doradzaliby konsultację psychologiczną i psychoterapię, która pozwoliłaby zrozumieć przyczyny takiego stanu (44,8\%). Nieco rzadziej proponowaliby zmianę stylu życia (36,2\%), a najrzadziej zgłoszenie się do psychiatry i farmakoterapię $(13,8 \%)$. Studenci zaczynający studia pielęgniarskie częściej wskazywali na poradę „psychoterapeutyczną" i „niemedyczną", natomiast kończący studia magisterskie znacznie częściej wybierali poradę typowo medyczną. Zależności te były istotne statystycznie $(\mathrm{p}=0,005)$ (rys. 1).

11 A.V. Horwitz, J.C. Wakefield, The medicalization of sadness: How psychiatry transformed a natural emotion into a mental disorder, [w:] The Medicalization of Life, eds. A. Maturo, P. Conrad, "Salute e Societa" 2009, Vol. 8 (2), DOI: http://10.3280/SES2009-EN2005, s. 49.

12 Krytyka tego typu obejmuje nie tylko depresję, ale też inne zaburzenia psychiczne, których przyczyn upatruje się w tzw. chemicznej nierównowadze mózgu. Zob. J. Leo, J.R. Lacasse, The media and the chemical imbalance theory of depression, "Society" 2007, No. 45, s. 35-45. 
Pobrane z czasopisma Annales I - Philosophy and Sociology http://philosophia.annales.umcs.pl Data: 26/04/2023 14:22:56

Poglądy studentów pielęgniarstwa na temat stanów, zachowań...

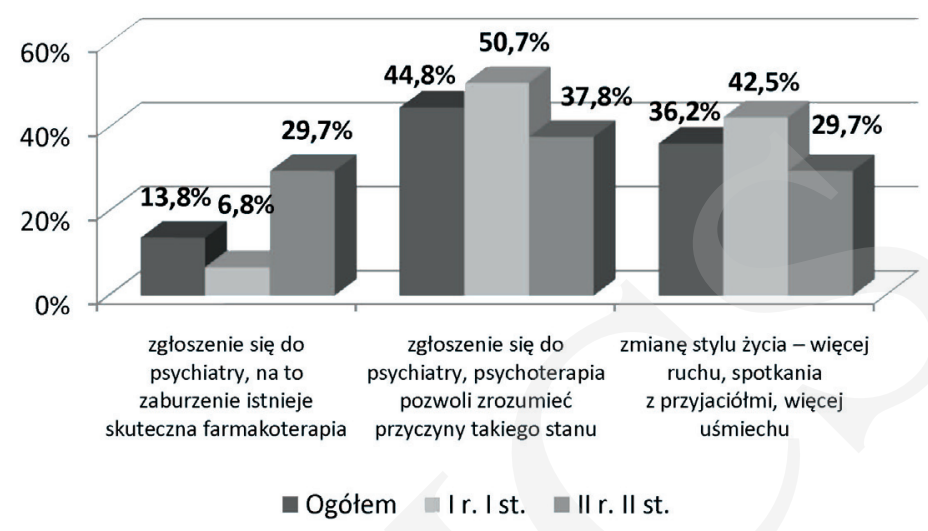

Rys. 1. Porady, jakich udzieliliby badani osobie z depresją

Źródło: opracowanie własne.

\section{ZAKUPOHOLIZM}

Zakupoholizm nie jest wyodrębnionym zaburzeniem w najczęściej używanej klasyfikacji zaburzeń psychicznych Amerykańskiego Towarzystwa Psychiatrycznego DSM (Diagnostic and Statistical Manual of Mental Disorders). Nie znajdziemy go również w klasyfikacji chorób WHO ICD (International Clasification of Diseases). Możliwe jednak, że za jakiś czas znajdzie się w wyżej wymienionych klasyfikacjach jako jedno z zaburzeń behawioralnych. Zdecydowaliśmy się włączyć to zachowanie do naszej ankiety, ponieważ jest to ciekawy przykład zachowania dewiacyjnego, które jest w trakcie medykalizacji - podobnie jak depresja jest ono biologizowane: w psychiatrii szuka się jego przyczyn (i innych uzależnień behawioralnych) m.in. w małym stężeniu serotoniny i dopaminy w mózgu ${ }^{13}$.

Zakupoholizm najczęściej postrzegany był przez respondentów w kategoriach psychologicznych jako „forma zachowań kompensujących, sprawianie sobie przyjemności, odreagowanie stresu” (48,3\%) oraz medycznych - „uznane w psychiatrii zaburzenie psychiczne, uzależnienie" $(43,1 \%)$. Nieliczni wybierali definicję socjologiczną - „skutek promowanej w społeczeństwie konsumpcyjnym formy rozrywki i zaznaczenia statusu" (7,8\%). Badani uczęszczający na studia I stopnia częściej wskazywali na definicję „społeczną”, a kończący studia na poziomie magisterskim - na „psychologiczną”. Różnice te były jednak na granicy istotności statystycznej ( $\mathrm{p}=0,057)$ (rys. 2).

13 B. Lelonek-Kuleta, Uzależnienia behawioralne na tle współczesnej wiedzy o uzależnieniach, „Studia Społeczne” 2015, nr 12 (1), s. 101. 
Pobrane z czasopisma Annales I - Philosophy and Sociology http://philosophia.annales.umcs.pl Data: 26/04/2023 14:22:56

Preferowanym sposobem rozwiązania tego problemu wyjątkowo była „wizyta u psychiatry i farmakoterapia” $(2,6 \%)$, a przede wszystkim ,wizyta u psychoterapeuty" (52,6\%) lub ,znalezienie sobie innych rozrywek, metod prezentowania swojej tożsamości” $(43,1 \%)$. Początkujący studenci częściej proponowali znalezienie innych rozrywek, natomiast kończący studia wskazywali psychoterapię. Zależności te były na granicy istotności statystycznej ( $\mathrm{p}=0,057)$ (rys. 3).

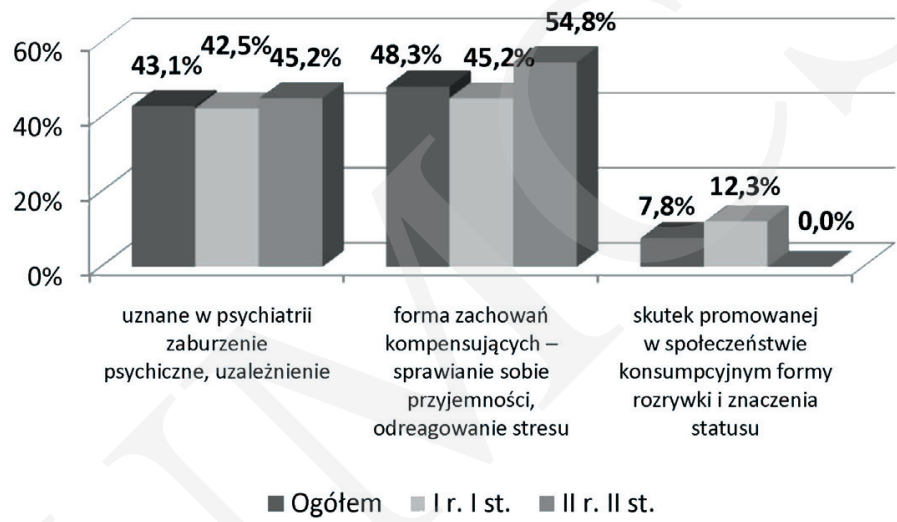

Rys. 2. Zakupoholizm w opinii studentów pielęgniarstwa

Źródło: opracowanie własne.

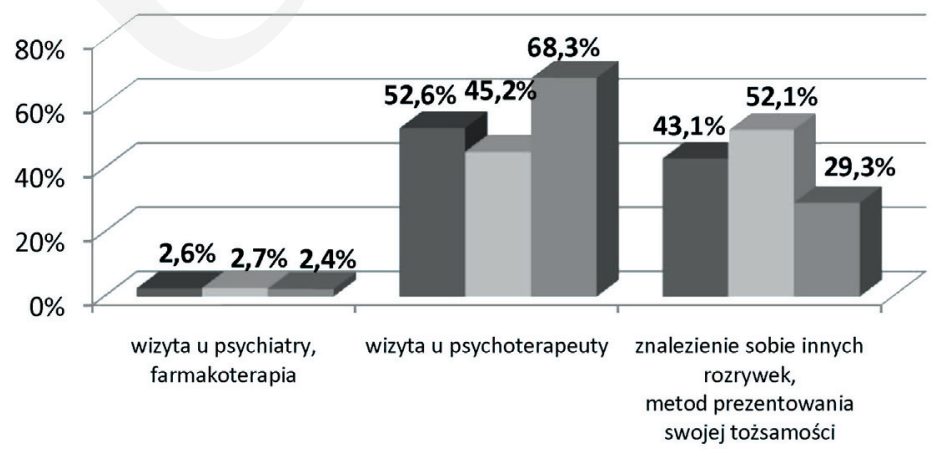

Ogółem $\quad$ I r. I st. $\quad$ || r. II st.

Rys. 3. Porady, jakich udzieliliby badani zakupoholikowi

Źródło: opracowanie własne.

\section{ZABURZENIA EREKCJI}

Zaburzenia erekcji są intensywnie medykalizowanym problemem. Dużą rolę w tym kontekście odegrało wynalezienie i komercyjny sukces leku o nazwie 
Pobrane z czasopisma Annales I - Philosophy and Sociology http://philosophia.annales.umcs.pl Data: 26/04/2023 14:22:56

Poglądy studentów pielęgniarstwa na temat stanów, zachowań...

handlowej Viagra. Według krytyków medykalizacji zaburzenia erekcji w rzadkich przypadkach są wynikiem problemów o charakterze fizjologicznym, natomiast ze względów głównie ekonomicznych leczone są obecnie prawie wyłącznie za pomocą środków farmakologicznych. Co więcej, do takich terapii namawiani są coraz młodsi mężczyźni (głównie za pośrednictwem reklam). Tymczasem za większość problemów z erekcją (zwłaszcza łagodniejszych) odpowiadają problemy psychologiczne, stres, przepracowanie oraz problemy w ramach związków małżeńskich ${ }^{14}$.

W naszych badaniach zaburzenia erekcji zdaniem zdecydowanej większości badanych to „efekt stresu, przepracowania, niskiej samooceny” (66,4\%). W opinii $1 / 4$ to „groźny sygnał zaburzeń o podłożu biologicznym” (25,9\%). Nieliczni stwierdzali, że jest to „skutek problemów małżeńskich” (4,3\%).

Paradoksalnie w sytuacji zaburzeń erekcji studenci pielęgniarstwa radziliby przede wszystkim wizytę u lekarza i farmakoterapię (56,9\%), rzadziej wizytę u psychoterapeuty (25\%) czy terapię małżeńską (12,9\%).

\section{PORÓD}

Poród jest jednym z najczęściej poruszanych tematów w literaturze dotyczącej medykalizacji. Model opieki okołoporodowej jest żywo dyskutowaną kwestią, a spierających się o niego można podzielić na dwa skrajne obozy: $z$ jednej strony stoją lekarze położnicy, dla których poród to czynnik ryzyka zdrowotnego, proces, który trzeba monitorować i aktywnie prowadzić, natomiast z drugiej strony są zrewoltowane położne i kobiety, które widzą w porodzie proces rządzący się swoimi prawami, natomiast „ekspertami” od porodu są ciała matek i ich dzieci, które instynktownie wiedzą, jak się zachować. W tym drugim ujęciu zdecydowana większość interwencji medycznych jest $\mathrm{w}$ trakcie porodu niepotrzebna i szkodliwa ${ }^{15}$.

Poród w opinii ankietowanych to najczęściej ,naturalny proces fizjologiczny i tylko wyjątkowo powinien być poddany procedurom medycznym" $(44,8 \%)$ lub „obarczony ryzykiem proces, który powinien być stale monitorowany przez lekarzy” (33,6\%), rzadziej - „zagrożenie zdrowia, personel medyczny powinien go stale monitorować i aktywnie prowadzić" (21,6\%). Studenci z dyplomem pielęgniarstwa, kończący studia II stopnia, znacznie częściej wskazywali na poród jako naturalny proces fizjologiczny, zaś dla studentów rozpoczynających studia licencjackie

14 M. Nowakowski, Medykalizacja seksualności człowieka - konstruowanie zaburzeń w nadziei na zysk, [w:] Zdrowie i choroba w badaniach socjologicznych prowadzonych na Uniwersytecie Medycznym w Lublinie 1995-2013, red. W. Piątkowski, Lublin 2013, s. 105-122.

15 J.E. Lothian, 6 zasad wspierajacych przebieg normalnego porodu. Zasada Czwarta-unikaj interwencji nieuzasadnionych medycznie, www.rodzicpoludzku.pl/images/stories/publikacje/ zasady/zasada_czwarta.pdf [dostęp: 26.07.2016]. 
Pobrane z czasopisma Annales I - Philosophy and Sociology http://philosophia.annales.umcs.pl Data: 26/04/2023 14:22:56

częściej był to proces obarczony ryzykiem, a nawet zagrożenie zdrowia. Różnice odpowiedzi były istotne statystycznie $(\mathrm{p}=0,000)$ (rys. 4).

Respondenci zdecydowanie najczęściej doradzaliby kobiecie w ciąży, aby zdecydowała się na poród szpitalny, jednak bez stosowania zbędnych interwencji medycznych $(86,2 \%)$. Nieliczni radziliby cesarskie cięcie $(8,6 \%)$ lub poród domowy $(4,3 \%)$.

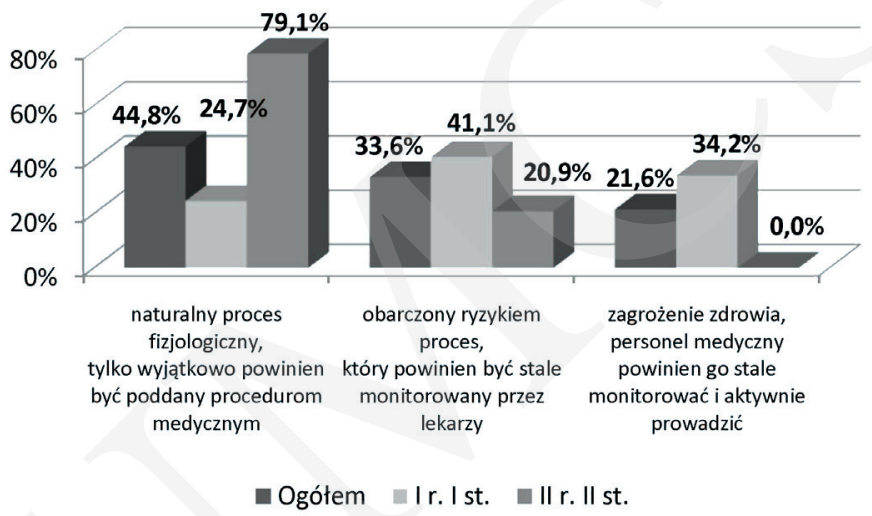

Rys. 4. Poród w opinii studentów pielęgniarstwa

Źródło: opracowanie własne.

\section{OSTEOPOROZA}

W literaturze na temat medykalizacji starości wątek osteoporozy pojawia się dość często ${ }^{16}$. Autorzy tych prac przede wszystkim krytykują traktowanie osteoporozy jako choroby, gdyż oznacza ona związany z naturalnym starzeniem się proces demineralizacji kości, który dotyczy każdego człowieka po pięćdziesiątce (choć jego tempo nie dla wszystkich jest jednakowe), oraz poddają w wątpliwość zasadność stosowania intensywnie promowanych terapii mających zapobiegać

16 M. Erol, Melting bones: The social construction of postmenopausal osteoporosis in Turkey, "Social Science \& Medicine" 2011, Vol. 73 (10), DOI: http://10.1016/j.socscimed.2011.08.033, s. 1490-1497; N.M. Hadler, Worried Sick: A Prescription for Health in an Overtreated America, Chapel Hill 2008; P. Kaufert, P. Gilbert, Women, menopause, and medicalization, "Culture, Medicine and Psychiatry" 1986, Vol. 10 (1), DOI: http://10.1007/BF00053260, s. 7-21; R. Moynihan, I. Heath, D. Henry, Selling sickness: The pharmaceutical industry and disease mongering, "British Medical Journal" 2002, Vol. 324 (7342), DOI: http://dx.doi.org/10.1136/bmj.324.7342.886, s. 886-891; N. Worcester, Hormone Replacement Therapy (HRT): Getting to the heart of the politics of women's health?, "National Women's Studies Journal” 2004, Vol. 16 (6), DOI: http://10.2979/NWS.2004.16.3.56, s. 56-59; J. Wright, Marketing disease: Is osteoporosis an example of 'disease mongering'?, "British Journal of Nursing" 2009, Vol. 18 (17), DOI: http://10.12968/bjon.2009.18.17.44163, s. 1064-1067. 
Pobrane z czasopisma Annales I - Philosophy and Sociology http://philosophia.annales.umcs.pl Data: 26/04/2023 14:22:56

Poglądy studentów pielęgniarstwa na temat stanów, zachowań...

71

osteoporozie. Moynihan, Heath i Henry uważają, że terapie mające zapobiegać postępującemu wraz z wiekiem zmniejszaniu się masy kostnej - obok analogicznych terapii mających pomagać w rozwiązywaniu takich problemów, jak wysokie ciśnienie krwi czy wysoki poziom cholesterolu - legitymizowane są przez przekształcanie tych czynników ryzyka w choroby ${ }^{17}$. Opracowana przez WHO definicja osteoporozy jest skonstruowana w taki sposób, że grupa ryzyka jest bardzo liczna. Według owej definicji chorobą jest niska gęstość minerału kostnego, ale normę wyznacza szczytowa gęstość kości u młodych kobiet i na tej podstawie ocenia się kości kobiet starszych. Wynika z tego, że zdrowe kości mają jedynie osoby młode, a co za tym idzie jako proces chorobowy w gruncie rzeczy musimy zacząć traktować samo starzenie się ${ }^{18}$.

Osteoporozę częściej niż co drugi ankietowany definiował w kategoriach „choroby polegającej na patologicznej demineralizacji kości, która bezpośrednio prowadzi do złamań" (60,3\%), dla co trzeciego był to „skutek naturalnego procesu demineralizacji kości, który jest przejawem starzenia się organizmu" (32,8\%), nieliczni wskazywali na ,istotny czynnik ryzyka złamania kości w wyniku wypadku” (4,3\%). W opinii studentów studiów licencjackich częściej był to skutek naturalnej demineralizacji, a dla kończących studia magisterskie - choroba polegająca na patologicznej demineralizacji. Zależności były istotne statystycznie $(p=0,014)$ (rys. 5).

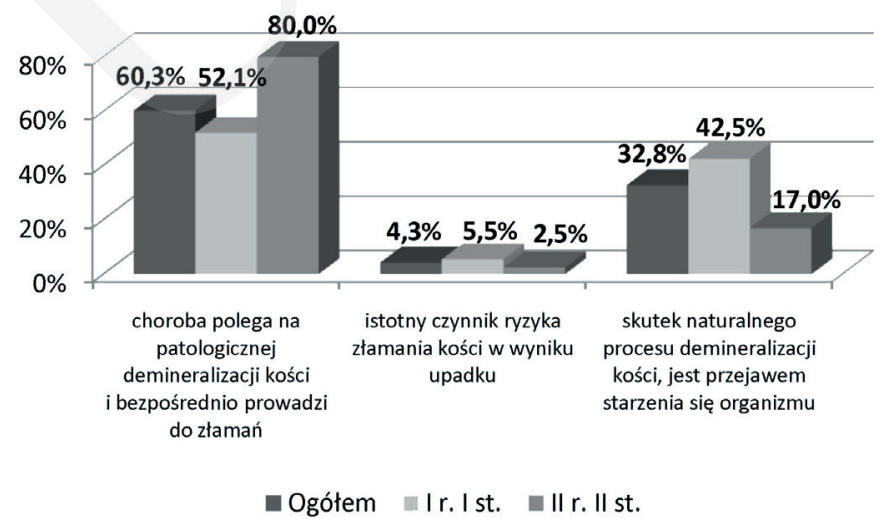

Rys. 5. Osteoporoza w opinii studentów pielęgniarstwa

Źródło: opracowanie własne.

17 R. Moynihan, I. Heath, D. Henry, op. cit., s.889.

18 WHO Scientific Group on the Assessment of Osteoporosis at Primary Health Care Level Summary Meeting Report, Brussels, Belgium, 5-7 May 2004, www.who.int/chp/topics/Osteoporosis.pdf [dostęp: 25.07.2016]. 
Pobrane z czasopisma Annales I - Philosophy and Sociology http://philosophia.annales.umcs.pl Data: 26/04/2023 14:22:56

Osobie z potwierdzoną testami osteoporozą badani radziliby przede wszystkim wizytę u lekarza i farmakoterapię (51,7\%), znacznie rzadziej opowiadali się za „suplementacją witaminy D i większą ilością czasu spędzanego na słońcu” (25\%) czy „ćwiczeniami wzmacniającymi mięśnie i ogólną sprawność, aby zmniejszyć ryzyko upadków" (14,7\%).

\section{OTYŁOŚĆ}

W dyskursie publicznym o otyłości mówi się obecnie jako o jednej z chorób cywilizacyjnych. Jest ona bezsprzecznie czynnikiem ryzyka wystąpienia wielu problemów zdrowotnych - powinna być w orbicie zainteresowań pracowników służby zdrowia oraz ważną kwestią w polityce prozdrowotnej państwa i społeczności lokalnych. To, czy człowiek w trakcie swojego życia stanie się otyły, zależy od wielu czynników. W naszych badaniach wybraliśmy przykład otyłości, żeby sprawdzić, czy studenci pielęgniarstwa skłonni są postrzegać ją w kategoriach zmedykalizowanych jako predyspozycję organizmu.

Według naszych respondentów otyłość to częściej „zjawisko społeczne, skutek zbyt dużej promocji i podaży wysokokalorycznej żywności” (44,8\%) niż „,choroba, która wynika z genetycznych predyspozycji organizmu” (33,8\%) czy „efekt indywidualnych decyzji dotyczących realizacji złych nawyków żywieniowych” $(18,1 \%)$.

Osobie otyłej, która chce schudnąć, 3/4 badanych poradziłoby „zmianę stylu życia - zdrowszą dietę i dużo ruchu” (75\%), nieliczni radziliby „wizytę u dietetyka, trenera" (15,5\%) czy „testy genetyczne, badania lekarskie, odsysanie tłuszczu lub operację żołądka" $(0,9 \%)$.

\section{DYSKUSJA}

Publikacje dotyczące medykalizacji w zdecydowanej większości prezentują rozważania i analizy teoretyczne; nieliczne prace opisują wyniki badań empirycznych, a te często polegają na analizach dyskursu, zawartości prasy, reklam, spożycia leków itd. Ze względu na unikatowy charakter prezentowanych danych nie sposób porównać je $\mathrm{z}$ rezultatami innych autorów. W tym kontekście jednak należy zwrócić uwagę na trudności, jakie pojawiają się w realizacji tego typu projektów badawczych.

Procesy medykalizacji następują $\mathrm{w}$ różnym tempie, nawet $\mathrm{w}$ obrębie jednej analizowanej pod wieloma względami społeczności. Mogą one polegać na genetyzacji stanu, zjawiska czy zachowania lub jedynie na jego farmakologizacji; realizowane są także w sytuacjach, kiedy procedury medyczne są stosowane w stanach, które nie są jednocześnie nawet patologizowane (tzn. nie traktuje się ich 
Pobrane z czasopisma Annales I - Philosophy and Sociology http://philosophia.annales.umcs.pl Data: 26/04/2023 14:22:56

Poglądy studentów pielęgniarstwa na temat stanów, zachowań...

jako choroby). Wszystko ostatecznie zależy od charakteru i sposobu interpretacji konkretnych przykładów zjawisk poddawanych medykalizacji. Wydaje się, że z tego powodu wyniki naszych badań są dość niejednoznaczne. Ponadto praca nad prezentowanym fragmentem projektu skłania nas do pewnej refleksji metodologicznej. Ostrożnie trzeba formułować pytania, na podstawie których chce się oceniać poziom zmedykalizowania badanych. Mamy wrażenie, że drobne zmiany w sposobie formułowania pytań i proponowanych do wyboru odpowiedzi mogą skutkować zasadniczo odmiennymi rezultatami.

W efekcie szczególnych uwarunkowań merytorycznych i metodologicznych, jakie pojawiają się w badaniach dotyczących medykalizacji, osiągnęliśmy bardzo ciekawe i jednocześnie trudne do jednoznacznej interpretacji wyniki. Okazało się, że ci sami respondenci mogą mieć w odniesieniu do różnych stanów, zjawisk czy zachowań zasadniczo odmienne poglądy.

Studenci pielęgniarstwa $\mathrm{z}$ jednej strony patrzą w bardzo zmedykalizowany sposób na osteoporozę (ponad 60\% uważa ją za „chorobę polegającą na patologicznej demineralizacji kości, która bezpośrednio prowadzi do złamań”, a ponad połowa radziłaby ,wizytę u lekarza i farmakoterapię”), a z drugiej strony rzadko w ten sposób definiują depresję (jako ,chorobę neurologiczną wynikającą ze zbyt niskiego poziomu serotoniny w mózgu" rozumiało jedynie $17 \%$ z nich, niecałe 14\% radziłoby zgłoszenie się do psychiatry i farmakoterapię).

Analiza uzyskanych danych wykazała także, że ci sami respondenci skłonni byli definiować konkretne stany, zachowania i naturalne procesy życiowe w zmedykalizowany sposób, ale jednocześnie preferowali psychologiczne bądź niemedyczne sposoby zaradzenia im (przykładowo spośród 49 osób, które jako definicję zakupoholizmu wybrały odpowiedź: „uznane w psychiatrii zaburzenie psychiczne, uzależnienie", jedynie dwie osoby jako sposób radzenia sobie z tym problemem uznały ,wizytę u psychiatry, farmakoterapię").

Jednym z celów realizacji prezentowanych badań była próba odpowiedzi na pytanie, czy studenci kończący studia pielęgniarskie na poziomie magisterskim częściej - w porównaniu z tymi, którzy rozpoczęli je na poziomie licencjackim wybrane zachowania, niedyspozycje czy naturalne procesy życiowe postrzegają w kategoriach typowo medycznych. Niestety, uzyskane dane nie pozwalają sformułować jednoznacznej odpowiedzi. W przypadku zaburzeń erekcji oraz otyłości osoby studiujące na poziomie magisterskim i licencjackim wybierały podobne odpowiedzi. Natomiast depresja, zakupoholizm i osteoporoza częściej były postrzegane w kategoriach typowo medycznych przez studentów kończących studia pielęgniarskie. W przypadku porodu uzyskaliśmy jednak odmienne rezultaty bardziej zmedykalizowanymi poglądami wykazali się studenci I roku studiów licencjackich. 
Pobrane z czasopisma Annales I - Philosophy and Sociology http://philosophia.annales.umcs.pl Data: 26/04/2023 14:22:56

\section{ZAKOŃCZENIE}

Na podstawie analizy uzyskanych danych można bardzo ostrożnie wnioskować, że w toku studiów pielęgniarskich następuje medykalizacja poglądów studentów wobec niektórych stanów, zjawisk i naturalnych procesów życiowych. Nie uzyskano jednak jednoznacznych rezultatów w odniesieniu do sześciu omawianych w niniejszej pracy przykładów. Wydaje się, że badania na ten temat, które opierają się jedynie na pytaniach zamkniętych, obarczone są dużym ryzykiem stworzenia badawczych artefaktów wynikających z określonej konstrukcji proponowanych w kafeteriach definicji. Dlatego w kolejnej publikacji planujemy zaprezentować wyniki porównania odpowiedzi uzyskanych w pytaniach zamkniętych i otwartych, które są w trakcie opracowywania.

\section{BIBLIOGRAFIA}

Conrad P., Medicalization and social control, “Annual Review of Sociology” 1992, Vol. 18, DOI: http://10.1146/annurev.so.18.080192.001233.

Conrad P., The discovery of hyperkinesis: Notes on the medicalization of deviant behavior, "Social Problems" 1975, Vol. 23 (1), DOI: http://dx.doi.org/10.2307/799624.

Conrad P., The Medicalization of Society: On the Transformation of Human Conditions into Treatable Disorders, Baltimore 2007.

Conrad P., Types of medical social control, "Sociology of Health and Illness" 1979, Vol. 1 (1), DOI: http://10.1111/j.1467-9566.1979.tb00175.x.

Davis J.E., How medicalization lost its way, "Society" 2006, Vol. 43 (6), DOI: http://10.1007/bf02698486.

Erol M., Melting bones: The social construction of postmenopausal osteoporosis in Turkey, "Social Science \& Medicine" 2011, Vol. 73 (10), DOI: http://10.1016/j.socscimed.2011.08.033.

Foucault M., Nadzorować i karać. Narodziny więzienia, Warszawa 1998.

Freidson E., Profession of Medicine: A Study of the Sociology of Applied Knowledge, New York 1970.

Furedi F., The end of professional dominance, "Society" 2006, Vol. 43 (6),

DOI: http://10.1007/BF02698479.

Goffman E., Asylums: Essays on the Social Situation of Mental Patients and Other Inmates, Doubleday (New York City) 1961.

Hadler N.M., Worried Sick: A Prescription for Health in an Overtreated America, Chapel Hill 2008.

Horwitz A.V., Wakefield J.C., The medicalization of sadness: How psychiatry transformed a natural emotion into a mental disorder, [w:] The Medicalization of Life, eds. A. Maturo, P. Conrad, "Salute e Societa" 2009, Vol. 8 (2), DOI: http://10.3280/SES2009-EN2005.

Illich I., Medical Nemesis. The Expropriation of Health, New York 1976.

Kaufert P., Gilbert P., Women, menopause, and medicalization, "Culture, Medicine and Psychiatry" 1986, Vol. 10 (1), DOI: http://10.1007/BF00053260.

Lelonek-Kuleta B., Uzależnienia behawioralne na tle współczesnej wiedzy o uzależnieniach, „Studia Społeczne" 2015, nr 12 (1).

Leo J., Lacasse J.R., The media and the chemical imbalance theory of depression, "Society" 2007, No. 45. 
Lothian J.E., 6 zasad wspierajacych przebieg normalnego porodu. Zasada Czwarta - unikaj interwencji nieuzasadnionych medycznie, www.rodzicpoludzku.pl/images/stories/publikacje/ zasady/zasada_czwarta.pdf [dostęp: 26.07.2016].

Moynihan R., Heath I., Henry D., Selling sickness: The pharmaceutical industry and disease mongering, "British Medical Journal" 2002, Vol. 324 (7342),

DOI: http://dx.doi.org/10.1136/bmj.324.7342.886.

Nowakowski M., Medykalizacja seksualności człowieka - konstruowanie zaburzeń w nadziei na zysk, [w:] Zdrowie i choroba w badaniach socjologicznych prowadzonych na Uniwersytecie Medycznym w Lublinie 1995-2013, red. W. Piątkowski, Lublin 2013.

Sadler J.Z., Jotterand F., Lee S.C., Inrig S., Can medicalization be good? Situating medicalization within bioethics, "Theoretical Medicine and Bioethics" 2009, Vol. 30 (6),

DOI: http://10.1007/s11017-009-9122-4.

Szasz T., The myth of mental illness, "American Psychologist" 1960, No. 15, DOI: http://dx.doi.org/10.1037/h0046535.

WHO Scientific Group on the Assessment of Osteoporosis at Primary Health Care Level Summary Meeting Report, Brussels, Belgium, 5-7 May 2004, www.who.int/chp/topics/Osteoporosis. pdf [dostep: 25.07.2016].

Worcester N., Hormone Replacement Therapy (HRT): Getting to the heart of the politics of women's health?, "National Women's Studies Journal" 2004, Vol. 16 (6),

DOI: http://10.2979/NWS.2004.16.3.56.

Wright J., Marketing disease: Is osteoporosis an example of 'disease mongering'?, "British Journal of Nursing" 2009, Vol. 18 (17), DOI: http://10.12968/bjon.2009.18.17.44163.

Zola I.K., Medicine as an institution of social control, "Sociological Review" 1970, Vol. 20, DOI: http://10.1111/j.1467-954X.1972.tb00220.x.

\section{SUMMARY}

The article is the presentation of the initial analysis of the results of research on the level of medicalization of nursing students' opinions towards selected conditions, behaviors, and natural biological processes, which are being medicalized. The study group seemed interesting to us, because it consists of people undergoing both medical training and shaped in the spirit of the holistic paradigm of nursing care, which should lead them to thinking about human and his problems not only in medical terms, but also in psychological and social. On the basis of six being medicalized conditions, behaviors, and natural biological processes (depression, compulsive buying, erectile dysfunction, childbirth, osteoporosis and obesity) we assessed the degree of medicalization of opinions of respondents. Depending on the example of the problem, the results are very different. Nursing students, on the one hand, have a very medicalised view of osteoporosis (more than $60 \%$ consider it as a disease), and on the other hand, rarely define depression in this way (depression as neurological disease is treated by only $17 \%$ of them). Moreover, by comparing the responses of students in the first year (undergraduate) and in the second year (MA), we concluded that the nursing studies rather reinforce medicalization of opinions of respondents. We have also come to the conclusion that reliance on the closed-ended questions does not give satisfactory effects: results they are too ambiguous and it is impossible to explain the internal contradictions in the responses of the respondents.

Keywords: medicalization; nursing; attitudes; depression; compulsive buying; erectile dysfunction; childbirths; osteoporosis; obesity 
Pobrane z czasopisma Annales I - Philosophy and Sociology http://philosophia.annales.umcs.pl Data: 26/04/2023 14:22:56

Renata Bogusz, Michał Nowakowski

\section{STRESZCZENIE}

Artykuł jest efektem pierwszych analiz wyników badań nad stopniem zmedykalizowania poglądów studentów pielęgniarstwa wobec wybranych stanów, zachowań i naturalnych procesów biologicznych poddawanych współcześnie medykalizacji. Badana grupa wydała się nam interesująca, ponieważ składa się z osób zarówno poddawanych szkoleniu medycznemu, jak i kształtowanych w duchu holistycznego paradygmatu opieki pielęgniarskiej, który powinien skłaniać ich ku myśleniu o człowieku i jego problemach zarówno w kategoriach medycznych, psychologicznych, jak i społecznych. Na podstawie sześciu współcześnie medykalizowanych stanów, zachowań i naturalnych procesów biologicznych (depresji, zakupoholizmu, zaburzeń erekcji, porodów, osteoporozy i otyłości) dokonaliśmy oceny stopnia zmedykalizowania postaw respondentów. W zależności od przykładu medykalizowanego problemu, wyniki są bardzo różne. Studenci pielęgniarstwa z jednej strony patrzą w bardzo zmedykalizowany sposób na osteoporozę (ponad 60\% uważa ją za chorobę), a $\mathrm{z}$ drugiej strony rzadko $\mathrm{w}$ ten sposób definiują depresję (depresję jako chorobę neurologiczną rozumiało jedynie $17 \%$ z nich). Ponadto, porównując odpowiedzi studentów I roku studiów I stopnia i II roku studiów II stopnia, uznaliśmy, że studia pielęgniarskie raczej sprzyjają medykalizacji postaw badanych. Jednocześnie doszliśmy do wniosku, że opieranie się na pytaniach zamkniętych nie daje zadowalających wyników, ponieważ są one niejednoznaczne i nie da się na ich podstawie wyjaśnić wewnętrznych sprzeczności w odpowiedziach badanych.

Słowa kluczowe: medykalizacja; pielęgniarstwo; depresja; zakupoholizm; zaburzenia erekcji; porody; osteoporoza; otyłość 